\title{
Thrombopoietin Receptor
}

National Cancer Institute

\section{Source}

National Cancer Institute. Thrombopoietin Receptor. NCI Thesaurus. Code C17695.

Thrombopoietin receptor ( $635 \mathrm{aa}, \sim 71 \mathrm{kDa}$ ) is encoded by the human MPL gene. This protein plays a role in thrombopoietin signaling and the regulation of both megakaryocytopoiesis and platelet formation. 